\title{
Mastectomy versus Radiotherapy as Treatment for Stage I-II Breast Cancer: A Prospective Randomized Trial at the National Cancer Institute
}

\author{
P.A. Findlay, M.D., M.E. Lippman, M.D., D. Danforth, Jr., M.D., H. McDonald, M.D., \\ T. d'Angelo, R.N., C.R. Gorrell, R.N., M.S.N., N.L. Gerber, M.D., W. Schain, Ed.D., and \\ A.S. Lichter, M.D. \\ Radiation Oncology Branch, Medicine Branch, Surgery Branch, Division of Cancer Treatment, National Cancer Institute; Cancer \\ Nursing Service, Rehabilitation Medicine, Clinical Care Consultant, Clinical Center, National Institutes of Health, Bethesda, \\ Maryland; and Department of Radiation Therapy, University of Michigan Hospital, Ann Arbor, Michigan, U.S.A.
}

In 1979, the National Cancer Institute in Bethesda, Maryland initiated a randomized, prospective trial to compare surgery versus radiation therapy in the treatment of stages I and II breast cancer. Surgical treatment consists of total mastectomy with axillary lymph node dissection (modified radical mastectomy) and breast reconstruction; radiation treatment consists of gross tumor excision, axillary lymph node dissection, and comprehensive irradiation including a boost dose to the tumor bed. All patients with pathologically positive axillary nodes receive 11 cycles of adjuvant Adriamycin ${ }^{\circledR} /$ Cytoxan $^{\circledR}$ chemotherapy. As of December 1984, there have been 175 patients entered in the study. Twenty-three patients have developed disease recurrence (12 mastectomy, 11 radiation), but it is too early to obtain definitive treatment-related results.

Over the last decade, changing concepts of tumor biology, improved therapeutic technology, and patient demands for treatment alternatives have wrought major change and heightened controversy surrounding the treatment of clinically localized breast cancer. The ideal therapy would not only be effective in curing the patient of cancer, but would do so with a minimum of physical disfigurement and psychological trauma. Although physicians agree on the desirability of these ends, argument over the best means to accomplish them is often heated.

Reprint requests: Peggie A. Findlay, M.D., Radiation Oncology Branch, National Cancer Institute/NIH, 9000 Rockville Pike, Building 10, Room B3B69, Bethesda, Maryland 20205, U.S.A.
Reports from single institutions [1-8] describing the outcome of various treatment techniques have been extremely encouraging in the movement away from disfiguring surgery. From such experiences, there are strong indications that treatment programs other than radical surgery, usually radiation therapy incorporated with limited surgical procedures, may well be capable of achieving comparable cure rates. However, the possibility of bias in these results due to patient selection has precluded unconditional acceptance of the equivalence of such alternative treatments. Appropriate clinical trials are necessary to answer the question definitively.

The results from 2 recent randomized trials, one from the Tumor Institute of Milan [9] and another from the National Surgical Adjuvant Breast and Bowel Project (NSABP) [10], which compare a surgical procedure incorporating breast amputation to treatment allowing for breast preservation are now available. Results from these important studies demonstrate that treatment that conserves the breast does not compromise survival in the study groups so tested at the present time of analysis. Neither study included all patients with clinical stages I and II breast cancer. In the Milan trial, only patients with clinical stage $T_{1} N_{0}$ cancers were accepted for treatment, while in the NSABP study tumor size was limited to $4 \mathrm{~cm}$ and patients with central tumors were excluded. Also, although both trials tested a radical surgical procedure incorporating breast removal against a breast-preserving treatment, differences in the specific treatments involved make direct comparisons difficult. In the Milan study, classic Halsted radical mastectomy, a 
Table 1. Treatment schema.

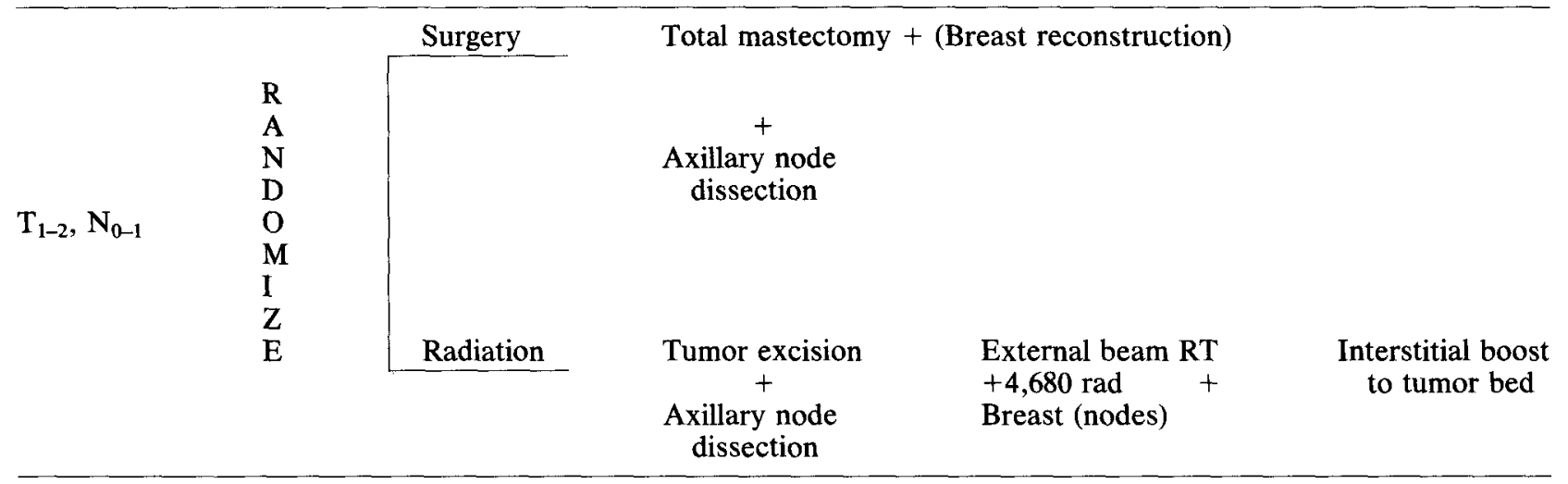

more extensive surgical procedure than the current standard, was compared to formal quadrantectomy with axillary dissection followed by breast irradiation. In the NSABP trial, the control arm, consisting of total mastectomy and axillary dissection (which has been the accepted and usual surgical approach in the United States), was compared to "segmental mastectomy" with and without radiation. Patients undergoing segmental mastectomy were required to have pathologically negative margins in the resected specimen. If margins were positive, the patient underwent an immediate total mastectomy. The surgery performed in a segmental mastectomy, particularly in terms of amount of surrounding normal tissue resected, is subject to great variability from patient to patient and surgeon to surgeon. Although both quadrantectomy and segmental mastectomy with negative margins preserve some portion of the breast, in many instances such resections result in a compromised cosmetic outcome.

In 1979, at the National Cancer Institute in Bethesda, Maryland, we initiated a randomized, prospective study. The purpose of the trial is to compare the current surgical treatment to comprehensive radiation therapy (Table 1).

Surgical management consists of total mastectomy with axillary dissection, followed by (optional) breast reconstruction. Several reconstruction options are available for our surgically managed patients. In the past, such procedures have involved placement of a prosthesis as well as creation of a breast mound using latissimus dorsi or rectus abdominus muscle. With use of these techniques, in order to optimize our ultimate cosmetic result, we delay breast reconstruction until the patient has recovered from her mastectomy and the local tissues have healed and stabilized. In patients not receiving chemotherapy, we can proceed as early as 3 months after the mastectomy. Patients who require chemotherapy have these surgical pro- cedures delayed until the completion of all courses of drug in order to avoid the possibility of infection and compromised wound healing. Recently, we have been able to offer patients an "immediate" reconstruction option. This involves placement at the time of mastectomy of a Silastic ${ }^{\circledR}$ tissue expander beneath the pectoralis major muscle. The device has an injection port which can be felt through the skin. Once the incision has healed, generally about 2 weeks, sterile saline can be percutaneously injected at periodic intervals through the port so as to expand the device gradually and with it the overlying tissues. Once an appropriate contour has been achieved, the tissue expander can be removed and the nipple-areola complex reconstructed at a second surgical procedure. This particular reconstruction option allows for rapid reconstitution of patient contour and eliminates the need for an external prosthesis even in patients who require chemotherapy and in whom the second procedure must be delayed.

Radiation treatment consists of gross tumor removal, axillary node dissection, and comprehensive regional irradiation. Tumor removal involves excision of the mass with a minimum of surrounding normal tissue, and does not require that the margins be pathologically free of microscopic tumor. Axillary dissection is performed through a separate incision and is virtually identical to the axillary surgery incorporated with total mastectomy. This assures us of an equivalent pathological nodal staging in the 2 treatment arms. Radiation treatment fields vary with tumor location and pathological status of axillary lymph nodes. The entire breast is irradiated in all patients. Patients with inner quadrant lesions receive, in addition, radiation to the internal mammary lymph nodes. Patients with pathologically positive axillary lymph nodes also receive radiation therapy to the internal mammary nodes as well as to the supraclavicular area. This is summarized in Table 2. We avoid irradiation of the 
Table 2. Radiation therapy treatment volume related to location of breast primary and pathologic node status.

\begin{tabular}{lll}
$\begin{array}{l}\text { Location of } \\
\text { breast tumor }\end{array}$ & \multicolumn{1}{c}{ Axillary lymph nodes } \\
\cline { 2 - 3 } Lateral & Negative & Positive \\
$\begin{array}{c}\text { Central and } \\
\text { medial }\end{array}$ & $\begin{array}{c}\text { Breast }+ \text { internal } \\
\text { mammary } \\
\text { nodes }\end{array}$ & $\begin{array}{c}\text { Breast }+ \text { supra- } \\
\text { internal mam- } \\
\text { mary nodes }\end{array}$ \\
\hline
\end{tabular}

fully dissected axilla except when there has been pathological demonstration of extranodal extension of cancer into the axillary fat. All patients undergo simulation and treatment planning computed tomographic (CT) scan. The breast is treated with opposing tangential fields which are angled to minimize beam divergence through the lung. Lung volumes are obtained on each patient through the use of CT scans, and lung density corrections are used in the calculation of dose to the tangential breast fields. Wedge beam modifiers are added as individually necessary to optimize dose homogeneity. An isodose plan is generated for at least 3 levels, including the central axis, and a prescription isodose is chosen that encompasses the entire breast tissue homogeneously. When internal mammary nodes are included in the treated volume, we prefer to include this region in the tangential fields, although in the unusual situation we have applied direct en face internal mammary field. When supraclavicular nodes are treated, this is accomplished with a direct anterior field, angled so that the exit dose avoids the spinal cord. All field edges are carefully matched using customized blocks and field angles to avoid over or under dosage at the edges of abutting fields. Patients are treated in the supine position on a $4-\mathrm{MeV}$ linear accelerator using 180 rad daily fractions to a total dose of $4,680 \mathrm{rad}$. In addition to $x$-ray treatment of the region, we incorporate a boost dose of radiation to the tumor bed. This is nearly always accomplished through use of an interstitial implant for which we use seeds of iridium 192, but in rare circumstances we have administered the boost dose using an electron beam. Total dose to the region of the tumor bed is about 6,300 rad.

All patients who demonstrate pathological involvement of 1 or more axillary lymph nodes are treated with 11 cycles of adjuvant chemotherapy consisting of Adriamycin ${ }^{\circledR} 30 \mathrm{mg} / \mathrm{m}^{2}$ and Cytoxan ${ }^{\circledR}$ $200 \mathrm{mg} / \mathrm{m}^{2}$. Drug dosages are escalated or reduced according to the schedule shown in Table 3.
Patients are eligible for this study if they have invasive breast cancer with a primary tumor up to 5 $\mathrm{cm}$ in diameter, clinically negative or clinically positive but movable axillary lymph nodes, and no evidence of distant metastases (AJC stage $T_{1-2}$, $\mathrm{N}_{0-1}, \mathrm{M}_{0}$ ). Patients are excluded if they have multiple primary breast tumors or a history of prior malignancy other than nonmelanoma skin cancer. All breast cancer treatment other than excisional biopsy of the primary tumor is performed at the National Cancer Institute. The patients are assigned by stratified block randomization to 1 of the 2 treatment arms, with stratification by age (less than 50 , greater than or equal to 50 years), clinical node status, and history of cardiac disease. We do not employ prerandomization.

As of December 31, 1984, there have been 175 patients entered in the study, of whom 85 randomized to surgery and 90 to radiation therapy. Median patient age is 50 years, with a range of 25 to 79 . The median number of axillary nodes examined is 23 , with a range of 8 to 60 , and does not differ between the two arms. Pathologically positive lymph nodes were found in 72 patients $(41 \%)$, of whom 38 had been assigned to mastectomy and 34 to radiation.

In addition to determination of treatment outcome in terms of survival and survival free of disease, we are investigating several other issues related to early breast cancer in our study patients. We have recently begun a study to test the feasibility of imaging axillary lymph node metastasis by the subcutaneous injection of monoclonal ${ }^{131}$ I-labeled anticarcinoma antibodies. Labeled antibody is injected into the finger webs, and the patient then undergoes serial scanning over several days. The axillary nodes are dissected according to our usual procedure, and the pathological node findings are compared to the scan results. We have reported previously that our technique of administering radiation therapy does not compromise delivery of systemic adjuvant chemotherapy, with a $100 \%$ median dose of Adriamycin ${ }^{\circledR}$ delivered in both arms, and median doses of delivered Cytoxan $(B) 110 \%$ and $115 \%$ in the radiation and surgery arms, respectively [11]. We feel that routine incorporation of reconstruction after mastectomy will allow us to compare realistically the psychological impact of our 2 local treatment modalities. We have previously reported on psychosocial outcomes of primary breast cancer therapy in our study population [12]. Upon completion of local therapy, patients were assessed for mood (anxiety, guilt, anger), attitudinal responses (feelings of concern that cancer might recur), and behavioral reaction (possible problems in eating, sleeping, or sexual response). Our patient population is uniquely suited to study the psychosocial impact of therapy since all study 
Table 3. Summary of chemotherapy.

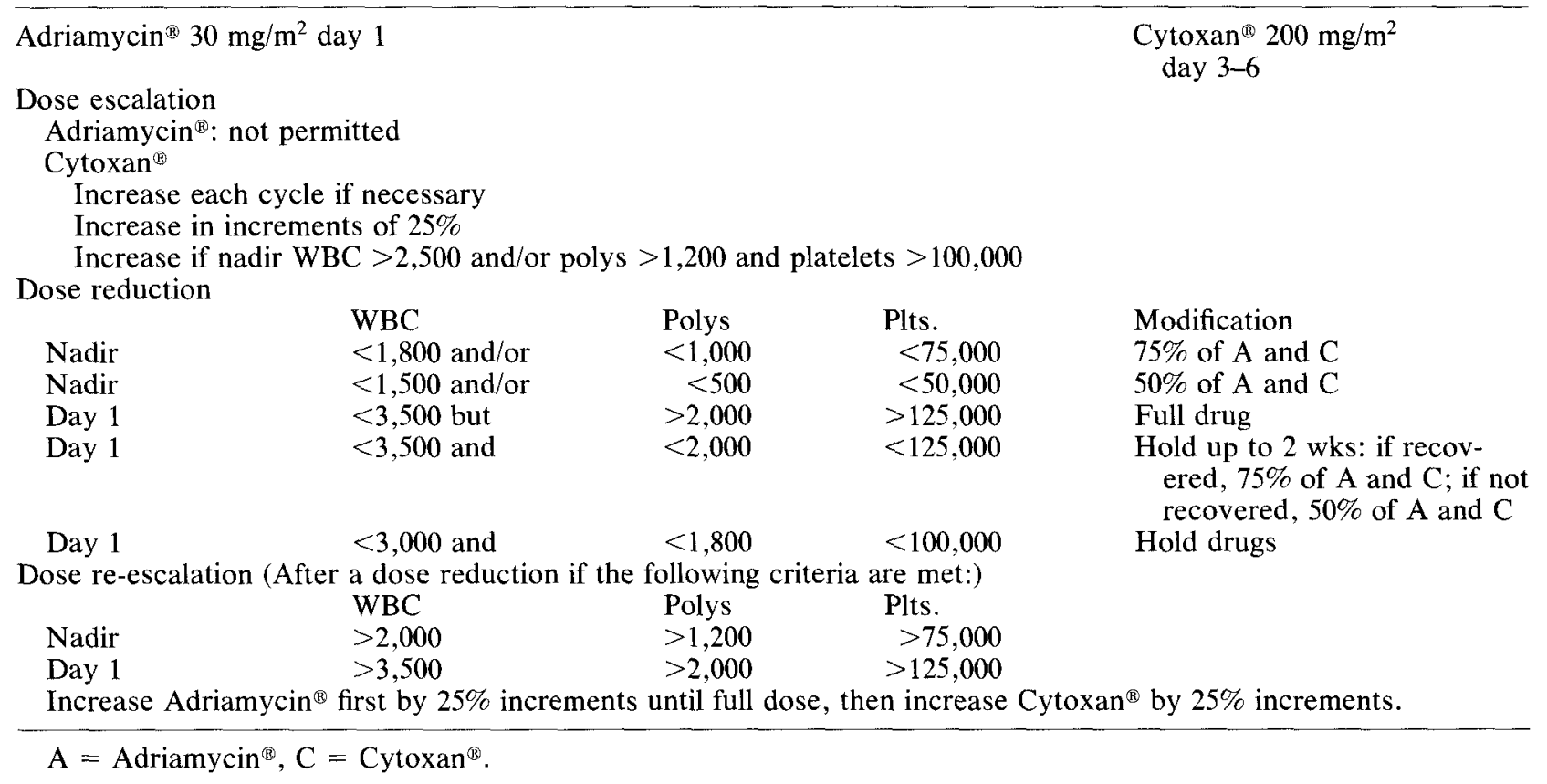

patients had accepted either mastectomy or radiation at study entry, were assigned at random to treatment, and are all seen jointly by the same health care team. When evaluated initially, the only psychosocial item that was statistically, significantly different between the 2 groups was a more negative reaction to self nude in mastectomy patients. Both groups reported fairly high degrees of anxiety and depression. A prospective psychosocial assessment of our patients examining the psychosocial adaptation to treatment over time is currently in progress. We are examining the functional outcome of the 2 local treatments in terms of shoulder range of motion, changes in arm circumference, and effect of various rehabilitative maneuvers on these parameters.

It is much too early to give definitive treatmentrelated results at this time. Twenty-three patients have developed disease recurrence to date (12 mastectomy patients, 11 radiation patients). Isolated local-regional recurrence in the breast/chest wall and/or ipsilateral axillary, supraclavicular, or internal mammary lymph nodes has occurred in 4 patients, 2 who underwent mastectomy and 2 who had radiation therapy. The 2 patients who underwent radiation therapy and developed local-regional recurrence had disease limited to the breast. Both underwent total mastectomy and are currently alive without evidence of disease 14 and 2 months after salvage surgery. If, with additional patients and longer follow-up, surgery and radiotherapy are shown to be equivalent in terms of cancer control and survival, the choice of best treatment will be determined by issues of toxicity and cosmesis.

\section{Résumé}

En 1979 l'Institut National du Cancer de Bethesda a lancé une étude prospective randomisée permettant de comparer les résultats respectifs de la chirurgie et de la radiothérapie en ce qui concerne les stades I et II du cancer du sein. Le traitement chirurgical consiste en la mastectomie totale complétée par le curage ganglionnaire axillaire (mastectomie totale modifiée); le traitement dit radiothérapique consiste en l'exérèse large de la tumeur associée au curage ganglionnaire axillaire et à l'administration d'une dose élevée de rayons au niveau du lit tumoral. Toutes les opérées dont les ganglions sont envahis reçoivent en outre 11 cycles d'une combinaison d'Adriamycine et Cytoxan. De 1979 à Décembre 1984, 175 malades ont fait l'objet de cette étude. Vingt-trois ont accusé une récidive (12 après mastectomie et 11 après traitement dit radiothérapique) mais il est encore trop tôt pour tirer des conclusions définitives de ces résultats.

\section{Resumen}

El Instituto Nacional de Cáncer de Bethesda inició en 1979 un ensayo prospectivo y aleatorio orientado a comparar el tratamiento quirúrgico versus radioterapia en el manejo del cáncer mamario en estados I y II. El tratamiento quirúrgico consistió 
de mastectomía total con disección ganglionar axilar (mastectomía radical modificada) y reconstrucción mamaria; el manejo radioterapéutico consistió de resección del tumor, disección de los ganglios linfáticos axilares e irradiación comprensiva incluyendo una dosis de refuerzo al lecho tumoral. Todos los pacientes con ganglios axilares histológicamente positivos recibieron 11 ciclos de quimioterapia adyuvante con Adriamicina/Citoxán. Hasta diciembre de 1984, 175 pacientes habían entrado al estudio. Veintitrés pacientes han desarrollado recurrencia de la enfermedad (12 mastectomía, 11 irradiación), pero es todavía muy temprano para derivar resultados definitivos.

\section{References}

1. Mustakallio, S.: Conservative treatment of breast carcinoma: Review of 25 years follow-up. Clin. Radiol. 23:110, 1972

2. Peters, M.V.: Cutting the "Gordon Knot" in early breast cancer. Presented at annual meeting of the Royal College, January 1975, pp. 186-191

3. Calle, R., Pillerson, J.P., Schlienger, P., Vilcoq, J.R.: Conservative management of operable breast cancer. Cancer 42:2045, 1978

4. Amalric, R., Santamaria, F., Forbert, F., Seigle, J. Altschuler, C., Kurtz, J.M., Spitalier, J.M., Brandone, H., Ayme, Y., Pollet, J.F., Burmeister, R., Abed, R.: Radiation therapy with or without primary limited surgery for operable breast cancer: A 20-year experience at the Marseilles Cancer Institute. Cancer 49:30, 1982

5. Pierquin, B., Otmezguine, Y., Lobo, P.A.: Conservative management of breast carcinoma. The Creteil experience. Acta Radiol. Oncol. 22:101, 1983

6. Harris, J.R., Hellman, S.: Results of primary radiation therapy for early breast cancer at the Joint Center for Radiation Therapy. In Conservative Management of Breast Cancer, New Surgical and Radiotherapeutic Techniques, J.R. Harris, S.
Helman, W. Silen, editors. Philadelphia, J.B. Lippincott, 1983, pp. 47-52

7. Prosnitz, L.R., Goldenberg, I.S., Weshler, Z., Lawrence, R.: Radiotherapy instead of mastectomy for breast cancer-The Yale exposure. In Conservative Management of Breast Cancer, New Surgical and Radiotherapeutic Techniques, J.R. Harris, S. Hellman, W. Silen, editors. Philadelphia, J.B. Lippincott, 1983, pp. 61-70

8. Montague, E.D., Schell, S.R., Romsdahl, M.M., Ames, F.C.: Conservation surgery and irradiation in clinically favorable breast cancer-The M.D. Anderson experience. In Conservation Management of Breast Cancer, New Surgical and Radiotherapeutic Techniques, J.R. Harris, S. Hellman, W. Silen, editors. Philadelphia, J.B. Lippincott, 1983, pp. 53-59

9. Veronesi, U., Del Vecchio, M., Greco, M., Luini, A., Muscolino, G., Rasponi, A., Saccozzi, R., Zucali, R.: Results of quadrantectomy, axillary dissection and radiotherapy (QU.A.RT.) in $T_{1} N_{0}$ patients. In Conservative Management of Breast Cancer, New Surgical and Radiotherapeutic Techniques, J.R. Harris, S. Hellman, W. Silen, editors. Philadelphia, J.B. Lippincott, 1983, pp. 91-99

10. Fisher, B., Bauer, M., Margolese, R., Poisson, R., Pilch, Y., Redmond, C., Fisher, E.R., Wolmark, N., Deutsch, M., Montague, E., Saffer, E.A., Wickerham, L., Lerner, H., Glass, A., Shibata, H., Deckers, P., Ketcham, A., Oishi, R., Russell, I.: Five-year results from the NSABP trial comparing total mastectomy to segmental mastectomy with and without radiation in the treatment of breast cancer. N. Engl. J. Med. 312:665, 1985

11. Lippman, M. E., Lichter, A.S., Edwards, B.K., Rice Gorrell, C., d'Angelo, T., DeMoss, E.V.: The impact of primary irradiation treatment of localized breast cancer on the ability to administer systemic adjuvant chemotherapy. J. Clin. Oncol. 2(1):21, 1984

12. Schain, W., Edwards, B.K., Gorrell, C.R., deMoss, E.V.,Lippman, M.E., Gerber, L.H., Lichter, A.S.: Psychosocial and physical outcomes of primary breast cancer therapy: Mastectomy vs. excisional biopsy and irradiation. Breast Cancer Res. Treat. $3: 377,1983$ 